Rachel Adcock, “Jack Presbyter in His Proper Habit”: Subverting Whig Rhetoric in Aphra Behn's The Roundheads (1682)', Women's Writing, 22:1 (2015), 34-55

This is an Accepted Manuscript of an article published by Taylor \& Francis in Women's Writing on 6 December 2014, available online: http://wwww.tandfonline.com/[http://dx.doi.org.uk/10.1080/09699082.2014.941182

\title{
“JACK PRESBYTER IN HIS PROPER HABIT”: SUBVERTING WHIG RHETORIC IN APHRA BEHN'S THE ROUNDHEADS (1682)
}

\begin{abstract}
Aphra Behn's The Roundheads (1st perf. 1681, pub. 1682) was produced during a propaganda battle between the Whigs and Tories and set during the Interregnum in order to draw parallels between parliamentary usurpation and the Whig plea for "liberty and property". This article explores several contexts for the play, discussing the political atmosphere of the early 1680s, using this to speculate on the play's propagandist message and its possible presentation in the theatre. In particular, it compares the annual Pope-burning processions with the play's final bonfire scene, showing how Behn subverts this tradition in order to punish the bumbling, nonconformist usurpers, and explores its presentation of the Puritan lay-preacher (and proto-Whig), Ananias. Behn is clearly interested in playing with and undermining Whig traditions, slogans, and rhetoric, and subverts these in several ways. However, although The Roundheads' anti-Whig message is undisputable, this article also considers whether the play questions the behaviour of the victorious (though rakish) cavaliers, particularly in their treatment of women. By considering the presentation of the "constant couple”, Freeman and Lady Desbro' (who seems unlikely to ever become Lady "Freewoman" owning her "liberty and property"), the article suggests that the play's message is more complex than Behn scholars have previously argued.
\end{abstract}

The year 1681 was a turning point in the battle between the Tories, loyal to the succession of James, the king's Catholic brother, and the radical Whigs who were lobbying for his exclusion. These arguments, better known as the Exclusion Crisis, were played out between 1678 and 1681, and were to resurface when James succeeded to the throne in 1685. Since 1678, when Titus Oates and Israel Tonge had reported a Catholic plot to kill the king, which had coincided with the death of the man they told, Sir Edmund Godfrey, the City of London had become frightened of underground Popish plots and intrigues. ${ }^{1}$ Prominent politicians utilised these claims in order to bolster public opinion against the Duke of York, preferring Charles II's eldest illegitimate son, the Protestant Duke of Monmouth, for the succession. Charles was under pressure as reports of various plots were published in the press, and for a time, at least, it looked as if the exclusionists would have their way. However, following Charles's dissolution of the Exclusion Parliament at Oxford in March 1681, the tide turned in the loyalists' favour: sympathetic sheriffs were appointed in London and the private meetings of dissenters, so vocal in the press and pulpit in favour of exclusion, were suppressed and participants prosecuted. In order to persuade the people, the Tory press had to find ways of discrediting the exclusionists, which often included comparing the activities of parliamentary, particularly Presbyterian, figures in the lead up to the civil war in 1642 with the current radical and dissenting Whigs: no one wanted a repeat of the bloody civil wars, and this was therefore powerful propaganda. It is significant that the writing and staging of Aphra Behn's The Roundheads took place in December 1681, immediately after this controversy, and also playing its part in the war of words that followed. Reworking a Royalist Restoration play, 
John Tatham's The Rump (1660), Behn presents the 1659 Committee of Safety, led by John Lambert, as a set of power-hungry, bumbling upstarts whom the audience are encouraged to compare with contemporary Whig politicians: her additions to the plot, which include two "Heroik" cavaliers, Loveless and Freeman, as well as a loyal heroine, Lady Desbro', also allow the ageing and seeming-pious committee to be cuckolded, therefore affirming Royalist (updated as Tory) potency and supremacy. Whilst Behn scholars have noted the play's Toryism in its use of cuckoldry and desire, as well as debating whether this conflicts with Behn's expression of feminist ideas, this article seeks to highlight the play's defamiliarisation of Whig traditions and rhetoric in order to supplement these arguments. ${ }^{2}$

The Roundheads is intensely critical of Whig "canting" preachers and "scribbling" propagandists; for instance, the character performing the Prologue encourages Whig sympathisers to "Pay those that Rail, and those that can delude | With scribbling Nonsense the Loose Multitude". The play voices a distrust of the ability of Whig politicians and preachers to influence their listeners, and the stage offered Behn, as well as other playwrights, a platform to question these views voiced in the streets and pulpits. As Melinda Zook has noted, Behn "took some delight in parodying and mimicking the tropes and idioms of [her] opponents" in her work: ${ }^{4}$ in its subversion of Whig staged spectacles, slogans, and cant, The Roundheads is a particularly clear example of that mischief. This article will therefore explore the political atmosphere of the early $1680 \mathrm{~s}$, the context for the play, using this to speculate on the play's propagandist message and on staging possibilities (particularly its final bonfire scene and the presentation of its Puritan lay-preacher, Ananias). However, although the play's anti-Whig message is indisputable, this article will end by also considering whether the play questions the behaviour of the rakish cavaliers, particularly in their treatment of women. By considering the presentation of the "constant couple", Lady Desbro' and Freeman (the pun on "Freeman" drawing on both Whig and Libertine terminology), I will suggest that the play's message is more complex than has previously been recognised.

The Roundheads was produced and staged during a propaganda battle between Whig and Tory sympathisers, and finds its context in the street spectacles and written rhetoric that these arguments produced. Even after the king's dissolution of the Oxford Parliament, the Whig "Protestant Cause" continued to find sympathy with the London crowds. Zook argues that the attractiveness of Whig ideas came from a "combination of Whig practical politics, liberal political philosophies, and Protestant nonconformity". By associating the succession of the Duke of York with the rise of Popery, Whig rhetoric assured the people that under James they would be subjected to atrocities from a tyrannous and arbitrary ruler; their liberties and properties would be forfeit, and their parliament suppressed. The extent of antipopish feeling is visible in the increasingly crowded Pope-burnings that took place each year on 17 November to honour the anniversary of Elizabeth I's coronation, celebrating by extension the proposed succession of Monmouth, the Protestant heir. Such burnings were the culmination of elaborate processions where a crafted effigy of the Pope was paraded in his Chair of State by youths dressed as Catholic clergymen, along with other prominent "popish" figures. In order to produce a horrific "squalling" noise when the Pope was burnt on the bonfire, live cats were shut inside the effigy, their howls meant to represent the escape of devils and other evil spirits. ${ }^{6}$ By the time of the 1680 event, culminating at Temple Bar, the procession not only featured the Pope and his "Whore" of Babylon, but also an effigy of Roger L'Estrange, controller of the Tory press, and Elizabeth Cellier, the "Popish midwife" who had been accused of hiding subversive documents in her meal-tub (see figure 1). ${ }^{7}$ According to John Miller, the prominence of this festival, rather than the Gunpowder Treason celebrated on the 5 November, "implied a deep criticism of the court as falling short of Elizabethan perfection". ${ }^{8}$ Indeed, in 1679 , the Pope's effigy was made to bow to a statue of 
Elizabeth "adorned with a Crown of Gilded Laurel, in Her hand a Golden Shield, with this Motto Inscribed, THE PROTESTANT RELIGION, MAGNA CHARTA, and Flambeaus placed before it". 9 The result was a powerful, visual piece of propaganda that served to unite the people against Catholics, reminding the crowds of various "popish plots" (including the "martyred" body of Sir Edmund Godfrey, and Elizabeth Cellier's part in the Meal-Tub plot), whilst simultaneously mocking them. Processions such as these did not come cheap: Miller notes that the 1679 procession cost $£ 2,500$, financed in part by members of Whig clubs, and Tim Harris records that in the same year the effigy of the Pope itself cost $£ 100 .^{10}$ A pamphlet describing the procession of 1681 also recorded that "new Pageants and Devices have been prepared at the cost of such Loyal Citizens and others as have thereby shewn their Aversation and Detestation against Popery". 11

Behn's Prologue to The Roundheads, which appeared on the stage a month later, responded to these events. In it, the ghost of the parliamentary (read "Whig") commander and regicide, John Hewson, advises the audience to contribute money to this kind of propaganda in order to delude the people. He urges:

Pay Bully Whig, who Loyal writers bang

And honest Tories in Effigie hang:

Pay those that burn the Pope to please the fools

And doubly pay Right Honourable Tooles. $(365,11.25-28)$

Hewson's prologue refers to contemporary politics, including the Whig practice of paying for processions and effigies of "honest Tories": he has been "Rous'd by strange scandal, from th'eternal flame" (1. 3) to encourage the Whigs in their "Villainies" (1. 9). Here Behn recognised the effect of the Pope-burnings on the London crowds, while also showing her audience the seditious intent of those behind them, her method of satire reflecting that of the pageant designers: the ghost of Hewson works like an animated effigy on its way to be burnt. Earlier, in the Prologue to The Second Part of the Rover (performed before January 1681), Behn had satirised the "State-Cullies" whose "useful Purses" made the "Almighty Rabble" into "Publick Tools" to forward their own "private Int'rest". ${ }^{12}$ Her Epilogue to that same play satirises Elkanah Settle, a leading Whig propagandist and devisor of the Pope-burning processions of 1679 and 1680, who could only gain "a penny" from "forming Popes, and Squibs, and Crackers" (298, 11. 33-34). ${ }^{13}$ Later, in The Roundheads, Behn's addition of the "Joyner" who asserts the Whig slogan "Liberty and Property" referred to the "Protestant Joiner" Stephen College, so-called because he built several expensive effigies of the Pope for the bonfires, before he was executed for plotting against the king. ${ }^{14}$

The Roundheads was certainly part of the Tory response to the Whig propaganda effort which included the Pope-burnings. After Charles dissolved the Oxford Parliament the exclusion movement was effectively destroyed, but the Pope-burnings, now representative of the exclusionist cause and loved by the people, needed to continue in a different guise to satisfy the expectant crowds. "To defeat exclusion safely and successfully", Harris observes, "the government had to deal with the whig appeal to the people", and so the Tories launched a "counter-propaganda campaign" in order to win back popular support for the succession, to which Behn's play contributed. ${ }^{15}$ Though Behn's Prologue to The Second Part of the Rover claimed ironically that the voice of the "Rabble" could "impose even Laws on Kings" $(231,1$. 21 ), in 1681 the pressure on Charles from the City Whigs to change the law and recognise Monmouth as heir was a real concern. The Roundheads draws on the methods of other Tory propagandists by appealing to popular anxieties about popery and arbitrary government, but instead associating these with Whig-rule, represented in the play by the 1659 Committee of Safety, led by John Lambert. He addresses the Committee: "We'll tax the Nation high, the 
City higher; | They are our Friends, our most obsequious Slaves, | Our Dogs to fetch and carry, our very Asses" (3.1.255-57). The Tory press consistently referred back to actions of the Presbyterians in the period leading up to the civil wars, in 1640-42, and Behn also draws attention to this in her dedication, published with the play in 1682, where she writes that the "Rebellion, Murders, Massacres, and Villainies, from [16]40 upwards, should be Represented for the better undeceiving and informing of the World" (361, 11. 18-20). In other words, Presbyterians promoted anarchy and regicide. Hewson's Prologue echoes this sentiment, saying he has risen from hell

With noise of Plotts, of wonderous birth and name

Whilst the sly Jesuit robs us of our fame.

Can all their Conclave, tho' with Hell th'agree

Act mischief equal to Presbittery?

Look back on our success in Forty One,

Was ever braver Villainies carryed on

Or new ones now more hopefully begun. $(365,11.4-10)$

Behn utilises Hewson, as a forerunner of parliamentary Whiggism, to identify the Whigs as nonconformists, particularly Presbyterians, and to compare this particular kind of dissent with underground Catholicism. Hewson expresses concerns that the Jesuits, the bogeymen of the 1670s and 80s, should get more glory for their plots than the Presbyterian faction. Once this comparison was made, anti-Catholic feeling could also encompass a distrust of Protestant dissent, and Presbyterianism in particular. Perhaps unsurprisingly, in those turbulent times, Behn's authorship of the play provoked a Whig response that she deserved "to be swing' d" or hanged, like other Popish effigies (Dedication 362, 1. 49).

Encouraged by the installation of a Tory mayor in October 1681, and a shift in Tory propaganda techniques, Pope-burning events began to alter. On 5 November 1681, a month before the performance of Behn's play, the

Scholars of the Society of St. Peter's Colledge, Westminster, [...] having dressed up Jack Presbyter in his proper habit, they set him in a Tub, having in his right hand a Seditious Pamphlet, called Vox Patriae, and in his left a broad Scroll of Parchment, on which was written the Solemn League and Covenant: On his Cloak there was pinned another piece of Parchment, upon which was written Ignoramus; [...] they brought him to the Fire, which was prepared for their purpose, and setting about Ten Faggots more under the Tub, they burnt him down [...] at which a great Shout was given, everyone expressing Loyalty to His Majesty, and wishing that the real Person whom the Image represented, and all his Followers, had been burnt with it. ${ }^{16}$

The originator of these comments, reprinted in the anonymous dialogue, was Nathaniel Thompson, one of the leading Tory publishers of newsbooks, pamphlets, and ballads discrediting the exclusionist party. The "real Person" represented by Jack Presbyter was almost certainly Anthony Ashley Cooper, first Earl of Shaftesbury, who was then imprisoned in the Tower for treason in organising armed men to help force the king to exclude his brother. The infamous Whig pamphlet, Vox Patriae (1681), a collection of petitions directed to members of the Oxford Parliament urging them to vote against "Popery, Arbitrary Government, the Duke of York, or any Popish Successor", was burnt with the effigy, as well as the Solemn League and Covenant, the oath Shaftesbury had sworn in the 1640s to declare allegiance to the Parliamentary side. The Tory press had not forgotten that some prominent politicians had sworn allegiance to the Protectorate before the Restoration. The burning 
effigy also proved prophetic: Shaftesbury's jury, overwhelmingly Whig in sympathy, threw out the bill for his imprisonment on 28 November accompanied by the explanation "ignoramus". Fanning the flames of popular distrust in such a corrupt legal system, Behn's dedicatory epistle to The Roundheads expresses feigned disbelief that there would not be "one Rogue in the whole Generation of the Association" (i.e. the Protestant Whigs), and quotes "Ignoramus the $1^{\text {st }}$ and the $2 \mathrm{~d}$ " to show how justice had been ignored. The play itself contains a one-word allusion to "Tony" Shaftesbury himself when Whitlock, Lambert's Machiavellian schemer, explains to his master why oaths to monarchs need not be kept: "I took the Oath of Allegiance [to Charles I], as Oliver [Cromwell], your Lordship, Tony, and the rest did, without which, we could not have sat in that Parliament; but that Oath was not for our Advantage, and so better broke than kept" (1.2.308-11). Behn follows Tatham exactly in this speech except for her addition of Shaftesbury's name, highlighting to the audience his tendency to change sides for personal gain. Though Shaftesbury does not appear in the play, Behn's association of him with the Committee of Safety, who break their vows to their masters, their co-religionists, and fellow committee members, serves to confirm that the audience should read republicanism for Whiggism. The roasting of the Rump on a bonfire that ends the play, recalling the traditional Restoration bonfires where the hind-quarters of animals were burnt to celebrate the dissolution of the Rump Parliament, gains new meaning when considered against the background of Pope-burnings. Accompanied by the fall of the Committee members, some consigned to death and others to imprisonment, the staging of the bonfire, which would need to have been a real fire if it was to achieve the powerful visual effects of the Pope-burnings, reclaims the tradition for the Tories, confirming parliamentary Presbyterianism as a danger to the realm. ${ }^{17}$

By following Tatham, Behn recalls the burning of the Rump at the Temple Bar, but her play also works to re-appropriate the growing practice of Pope-burnings taking place in the early 1680s. Behn replaces the familiar effigies of the Pope with satirical presentations of the Puritans, precursors of the Presbyterian Whigs who, according to Tory writers, were enemies to rightful succession. Unlike in Tatham's play, where the Puritans are shown to return to their insalubrious beginnings as street sellers, in The Roundheads the Puritan characters seen as most worthy of humiliation are arrested before the bonfire and hoisted on cowl-staffs: John Hewson, the one-eyed cobbler who has sequestered the estate of Loveless, one of the fictional cavaliers; the Scottish Lord Wariston, also an ardent Presbyterian and much hated for his dealings with the English; and the fictional Ananias, the Presbyterian layelder who attempts to rape the heroine, Lady Desbro'. ${ }^{18}$ An eighteenth-century engraving titled "Burning ye Rumps at Temple Bar" (shown in figure 2), depicting the celebrations preceding the king's return, shows a number of effigies of "Respective Officers of State" carried astride cowl-staffs supported by the London crowds. To be hoisted on a cowl-staff signified a specific sort of punishment. The staff was "commonly used in 'ridings', a spectacle in which whores, adulteresses, cuckolds and wife-beaten husbands were 'ridden' through town, hoisted on a cowl-staff', legs astride it, and jeered at by their neighbours. ${ }^{19} \mathrm{~J}$. Douglas Canfield has argued convincingly that The Roundheads, quite unlike its source play, uses cuckolding to reinforce the virility and power of the cavaliers, who end the play winning back their sequestered estates through continuing or establishing relationships with women married to members of the Parliamentary Committee of Safety. ${ }^{20}$ Lady Maria Desbro' says that she has only married her Puritan husband in order to retrieve her lover Freeman's sequestered estate, and Loveless rescues Lady Lambert when she is threatened by the mob and her husband imprisoned. Hewson, Wariston, and Ananias are symbolic of the inept and impotent Presbyterian parliamentary cause, also representative of the Presbyterian Whig faction of the 1680s. Because of the backdrop of the Pope-burnings, the bonfire lit behind the men on cowl-staffs also hints towards the purgatorial function of Behn's drama. The audience 
of the time would have known Hewson as a regicide who lived the last part of his life in exile; that Wariston was hanged in Edinburgh for high treason in 1663; and that Hugh Peters, the chaplain to the council of state and an influence on the character of the lascivious layelder, Ananias, was executed on 16 October 1660 when the newsbooks opined that "there never was a person [as he that] suffered death so unpitied and (which is more) whose Execution was the delight of the people". ${ }^{21}$ Behn reclaims the Pope-burnings to suggest the violent deaths of rebellious parliamentary figures, implicating the Whigs in their treasonous activities. Following the falling fortunes of the exclusionists, and the production of Behn's play, 1682 saw an increase in Tory-sponsored bonfires, particularly anti-exclusion bonfires celebrated whenever the Duke of York returned to London. On 8 April 1682, for instance, an effigy of Jack Presbyter was burnt alongside the Rump, the Association, and the bill of exclusion, and in another place an effigy of Shaftsbury. ${ }^{22}$

Another aspect of the connection between The Roundheads and its source play is that it shares The Rump's preoccupation with display and pageantry. John Tatham had been chosen to design and organise the Lord Mayor's Shows between 1657 and 1664, including a pageant for Charles II's triumphal return to the city. As Richards writes, the Restoration of the monarchy saw a return to "public carnival" rather than the private masque popular with Charles I and Henrietta Maria: Restoration "pageantry [...] is organized in all its essentials to greet and compliment the sovereign, to banish the ogres of the past, to assert the regenerative force of the new king, and to weld and inspire the nation". ${ }^{23}$ Tatham's pageants celebrated good government as well as the purging of the previous ineffectual Puritan rule, and these themes also appeared in The Rump, performed in June 1660, a month after the return of Charles II. Behn's character list printed at the beginning of the play also indicates that, like her source play, she wanted to draw on contemporary city displays. She specifies that Ananias is of St Clement Danes Parish which held the main processional route linking the City and Westminster: The Strand culminating at Temple Bar, where both Rump and Popeburnings took place at various times. Months after the Rump burnings, on 22 and 23 April 1661, Charles II progressed along this route through the City from the Tower to Whitehall where he was crowned at Westminster. The Roundheads presents the lead up to the king's progress, but also relates these events to the opposition to the Duke of York's succession from Puritan Whigs who had tried to prevent proper monarchical succession.

Many of the scenes of misrule in The Roundheads, some of which are borrowed from Tatham, would not have looked out of place as processional tableaux leading up to street bonfires. ${ }^{24}$ The members of the Committee of Safety appear as exaggerated buffoons, some of whom would have been played by the comic double-act Anthony Leigh and James Nokes; the presumptuous, power-hungry Lambert provides a "mirror" for contemporary upstarts that would seek to take the crown for themselves; and Lady Lambert is ambitious, overruling her husband in order to groom him for greatness, and using her religion as a mask for political scheming. Her first appearance on stage has her emerging from a conventicle with her "train carried" and followed by her footmen and "Pages with great Bibles" (1.1.179 SD). She retreats to her prayer-book later in the play when she is caught entertaining her cavalier lover, hiding him under a carpet while she maintains her guise of virtue. An audience would not have to strain to see the comparison with the Pope's whore in the Pope-burning processions (see figure 1). Behn also reworks Tatham's parliament of ladies scene, a popular trope for the world turned upside-down where the wives of the committee of safety discuss the laws and practices of the commonwealth. Behn's main satirical addition, however, is Ananias, the lascivious preacher, who is blackmailed into distracting a gaoler so that the aptly-named cavalier "Freeman" can escape. When Ananias smuggles Freeman out of his beloved Lady Desbro's chamber later, under his cloak, Freeman exclaims that this is the "first Cloak of Zeal I ever made use of" (4.1.152), aligning Presbyterian plotting with the intrigue thought 
characteristic of popery. Such a moment would have made a striking visual tableau in a Popeburning procession.

Behn's addition of Ananias, who preaches to the conventicle attended by Lady Lambert, Lady Desbro', and the two cavaliers in the "half Hogs Head" inn (1.1.134), is an important part of the satire of The Roundheads. Loveless, who has apparently attended the conventicle against his will, observes that he would have liked to have "pull'd that Rogue of a Holder-forth by the Ears from his sanctify'd Tub", wondering why England should "suffer such Vermin to infect the Earth, such Wolves amongst thy Flocks, such Thieves and Robbers of all Laws of God and Man, in thy holy Temples" (1.1.139-41). The danger of infection from such preachers is expressed throughout the play: Freeman states that their "Rhetorick [...] can convert whole Congregations of well-meaning Block-heads, to errant Knaves" (4.1.3-5), though he makes use of Ananias's effective rhetorical skills that distract his gaoler while he escapes. This potential ability to rouse and provoke large groups of people to anarchy caused the Tories anxiety, who suspected that nonconformist zeal was disguising their revolutionary politics. Dissenting congregations offered potential male and female members the chance to join autonomous groups, emphasising the importance of individual conscience, as well as reading and interpreting scripture privately. These practices, combined with the Whig promotion of "Liberty and Property", were thought to give conventiclers the potential to become formidable opponents of the Loyalists who supported the succession. Tory anxiety led to a crack-down on city conventicles in the early 1680 s, recalling a similar anti-sectarian atmosphere to that of 1659-60. Whig Presbyterianism was also implicated in the exposed plots of Shaftesbury, College, and Rouse, influencing Behn's dedicatory epistle where "the Clouds already begin to disappear [...], thanks to [...] the Over-Zeal of the (falsly called) True Protestant Party", who, according to Loveless, were always "seeking the Lord for some great Mischief or other" (1.1.107). Behn suggests that the Whigs' "Over-Zeal" was self-defeating, dramatised through Ananias's uncontrollable "zeal" around the wife of his patron, enabling her to free her cavalier lover.

The Roundheads associates Ananias's Presbyterianism with popery, affirming that his zeal is more seditious than that of imaginary Catholic plotters: he is described by Lady Desbro', while he unashamedly fondles her breasts, as "the Head o'th' Church militant; the very Pope of Presbytery" (3.1.330-31). The militancy and rebellious potential of the dissenters is also indicated in Lady Desbro's earlier aside before Ananias's first appearance on stage: "he preaches nothing in his Conventicles, but Blood and Slaughter" (3.1.299-300). However, when Ananias appears, encouraging Lady Desbro' to remove her rich clothes because they are "an Abomination in the sight of the Righteous" (3.1.306), he seems less concerned with open warfare and more interested in his own private desires: his preaching is only a means to arouse women. A contemporary pamphlet, The Naked Truth, the title of which finds an echo in Ananias's speech, draws attention to the "Mock Religion of Conventicling" as "an holy Cheat at best", preaching consisting of "flat and impertinent expressions, Tautologies, [...] holy Knick-knacks and conceits, extemporary effusions, sanctifyed non-sense, and ridiculous Fopperies, which flow from such Pulpiteers Mouths; as insensibly and easily as excrements from some sick persons". ${ }^{25}$ Though attacked by Tory writers as a "holy Cheat", extempore preaching was seen to be manipulating language for the purposes of dissimulation and seduction, and could be, if used effectively, a useful method of disseminating Whig propaganda. In The Roundheads, Freeman declares "that Rhetorick [...] can convert whole Congregations of well-meaning Block-heads, to errant Knaves" (4.1.3-4). The play on the word "convert" is deliberate, for as well as "converting" followers spiritually, the conventicles infused their listeners with new and radical political ideas. ${ }^{26}$

The power of rhetoric to influence an audience is clearly something Behn wishes to satirise in her play. There are two exchanges between Lady Desbro' and Freeman where they 
converse by adopting the "tone" of either preachers or lawyers, the second of these including vows to marry when Lady Desbro's husband dies (which he does, conveniently, at the play's end). However, in addition to this, Behn's epilogue spoken by Lady Desbro', who reappears "High for the Royal Cause in Cavelier; | Though once as true a Whig as most of you" (423, 11. 2-3), includes a fifteen-line speech given in the manner of a Presbyterian knave "In $a$ Preaching Tone" (1.25 SD). This speech was presumably accompanied by a "gadly Sneere, the drawing of the Face to a prodigious length, the formal language, with a certain Twang through the Nose, and the pious Gogle", enough to "scare Children" (2.1.117-20), which Lady Lambert's maid Gilliflower describes earlier in the play. ${ }^{27}$ By demystifying the speeches of pulpit preachers in this way, highlighting the ease with which an actress can "perform" them, Behn shows men like Ananias to be nothing more than hypocrites, dissimulators, and cheats. Indeed, Montavalan's pamphlet The Naked Truth (1673) also depicts the ease with which a male critic might adopt the role of a preacher (in this case he calls himself "Mimologue") in order to obtain "pious" female followers. In bawdy terms, the "Sisters don't edify a like under all Teachers", but benefit from preachers that "mount the Pulpit with a Gigantean confidence as a Player doth the Stage, and there fulminate and tonitruate [thunder out] words to puzzle intellects". 28 The comparison between actor and preacher, stage and conventicler, was not lost on Behn, who utilises this for witty argument. Unlike Tatham's play, written for an audience in favour of the restored monarchy, Behn's audience, according to her dedicatory epistle, were largely hostile to her play and came to watch it "on the first day" because it had a "Loyal Title": "even the sober and tender conscienc'd, throng as to a forbidden Conventicle: fearing the Cub of their old Bear of Reformation should be expos'd, to the scorn of the wicked" (361, 11. 14-17). She continues: they flocked "in a full Assembly with a pious design to Hisse and Rail it as much out of countenance as they would Monarchy, Religion, Laws, and Honesty" (11. 20-21). Although considered a success by the "Royal Party" (the Tories), the play apparently drew "down Legions upon its head" from the Whigs in the audience, though whether this was expressed during or after the play is unclear.

The first appearance of the cavaliers, Freeman and Loveless, when they are leaving a conventicle in disgust at the beginning of The Roundheads, gains new meaning when opposed with Whigs' disgust at attending a "loyal" play at the theatre. Certainly, the ability of Whig preachers to influence and convert their listeners was considered dangerous, but Behn utilises the stage instead to persuade her audience. ${ }^{29}$ She even dramatises the conversion or reformation of characters to the Royalist cause: Lady Lambert is converted to cavalier values by Loveless (though she is already disposed to monarchical government), and the apprentices are won over by the rousing speech of their captain to which they reply, "we recant" (5.1.91). In the Prologue, the ghost of Hewson also warns that Whig witnesses need to be paid so that they are not tempted to "Recant" and turn "Honest" (365, 11. 20-21). The line between stage and pulpit is again blurred in the Epilogue where Behn defends the theatre from the attacks by the Whig faction:

But why gainst us do you unjustly arm

Our small Religion sure can do no harm,

Or if it do, since thats the only thing

We will reform, when you are true to th' King. $(424,11.45-48)$

Behn's extended comparison allows her to make the argument that if the theatre ("our small Religion") can be criticised for staging libellous "loyal" plays, causing opponents "to pray us harmless Players to the Devil" (1. 42), conventicles were guilty of the same crime. The theatre was also accused of licentiousness by Puritan dissenters, and Behn records that when their 
opponents could think of nothing else they attacked them because of their patron, the Duke of York, "our glorious Master" (1.44). Libellous and licentious behaviour in conventicles is dramatised in the play and held to account, and they are also shown not to be "true to th' King". Until the Whigs reform their conventicles and become loyal to the succession, Behn writes, the theatre will continue to produce plays that criticise them.

The behaviour of Whigs and their dissenting brethren is highlighted throughout The Roundheads, and shown to be in need of reform. Ananias justifies the views of him expressed by other characters in the play, that he is interested in exploiting his followers for money, although his targets are predominantly women whom he attempts to exploit for both money and sex. Lambert's advisor Whitlock clearly defines a preacher's function as making "Fools bring more Grist to th'publick Mill" (3.1.235). In the prologue, the ghost of Hewson proclaims, "let the Saints pay Pious Contribution" $(365,1.16)$, as well as "let the zealous Sisters pay" em too" (1.30), and Loveless further highlights this kind of behaviour when he expresses disgust at hearing "a Rascal hold forth for Bodkins and Thimbles, Contribution my beloved! to carry on the Good Cause, that is, Roguery, Rebellion, and Treason" (1.1.126-28). Opponents remembered the use made of contributions to uphold "Roguery" and "Rebellion" rather than spending these funds to amend the poor economic conditions of 1659. Tory writers, including Behn, presented the Rump, especially, as a government that could not adequately ensure prosperity. The members were, like Ananias, "Padders" that "rob on the High-way i'th'Pulpit", especially "poor Wenches of Bodkins and Thimbles" (5.1.110-16). In biblical terms, Ananias was a follower of Paul and the apostles and was asked to sell his land and belongings so that the people of God could combine their riches and hold "all things in common" where "distribution was made unto every man according as he had need" (Acts 4:32-35). However, Ananias lied and kept back part of the price and laid only a "certain part" at the apostles' feet (Acts 5:2), to which God responded by striking him dead. His body was "wound up" by "young men" who "carried him out and buried him" (Acts 5:6). Behn's readers would also have made the connection between the society of the apostles in the New Testament and the establishment of the 1650s commonwealth: in the play, Ananias is said to steal from others for his own gain, and to threaten the wealth of his fellow parliamentarians. The only property he wants to hold in common is women, shown in his assault on Lady Desbro'.

The name Ananias was clearly synonymous with "liar" or "cheat", and was also previously utilised by Ben Jonson in The Alchemist (1610), for a officious Puritan whose time is spent dealing in "widow's and with orphans' goods" which he wants turned into gold. ${ }^{30}$ It is also possible to see exaggerated characteristics of other seventeenth-century preachers in Behn's Ananias. An engraved caricature of Hugh Peters, circulating in 1662-63 after his execution, for instance, depicted him with a devil on his shoulder accumulating money bags labelled "bodkins and thimbles" and "sequestered benefices" from royalists, amongst others (see figure 3). Written underneath these money bags were the consequences of these "contributions": to "Starve Widows \& Orphans". Peters was also rumoured to be lascivious, several pamphlets rehearsing a story where he crept into the home of a pretty butcher's wife who had promised to leave him a key, but instead had left a trap which caught him by the arm until he was "disgracefully released". Jane Spencer has observed that Peters was a probable influence on the presentation of Tickletext, Behn's lascivious Puritan preacher in The Feigned Courtesans (1679). "Tickling" both the scripture, and women (particularly Italian whores), is what earns Tickletext the dubious title of "amorous Ananias". ${ }^{32}$ In The Roundheads, Lady Desbro' accuses Ananias of manipulating "kind, deluded Wives, whom you cant and goggle into a Belief, [...] till you sweat again, that the Sanctified Sisters may rub you down, to comfort and console the Creature" (3.1.367-71). Behn's play emphasises Ananias's predatory sexual urges, associating the exchange of money and goods with the 
exchange of wives, a charge that was absent from The Alchemist. This association is made explicit in the conversation between Lambert and Wariston, borrowed from Tatham, where they plan to rob the city of its riches to fund their own designs:

Lambert: Besides, the City's rich, and near her time, I hope, of being deliver'd.

Wariston: Wons a gued, wad I'd the laying o her, she shou'd be sweetly brought to Bed. (3.1.259-62)

Metaphors of sexual union and subsequent childbirth are used to define the men's plan to woo (or perhaps possess) the city so it will produce its gold; the process is clearly figured in terms of a man bedding a woman. Such an exchange also prefigures the moment where Ananias "ruffles" and attempts rape on Lady Desbro' when they are left alone, seeking to give her a "Babe of Grace", which further highlights the connection between sexual and monetary exchange (3.1.294-411 (336 SD, 363)). For instance, the Captain of the apprentices accuses Ananias of "Rob[bing] the Sisters, and preach[ing] it lawful for them to rob their Husbands" (5.1.114-15) in order to provide for him and his congregation. Thomas Edwards's catalogue of heresies observed in the 1640s included the knowledge that some gathered congregations considered it "lawfull for wives to give without their husbands consents, something out of their husbands estates, for the maintenance of the Church and Ministers whereunto they belong". ${ }^{33}$ Not only were sectarian preachers known for cuckolding husbands sexually, they also threatened the traditional order by giving women licence to dispose of their husband's money, their own having been subsumed upon marriage. In keeping with this, Ananias attempts to steal men's wives (and he has succeeded previously, if the audience can believe him), and also steals money and estates. Behn's Epilogue emphasises the contemporary perception of Presbyterians as secretive and manipulative, linking this to the plots of the age: "And when you can't prevaile by open force, | To cunning tickling tricks you have recourse, | And raise Sedition forth without remorse" (423, 11. 22-24). Behn's play accords political significance to this kind of sexual exchange: Whigs disrupted hereditary property rights by cozening goods, cuckolding their masters, and rebelling against the law, which also indicated their support for disrupting the lawful succession of the crown.

Whereas Ananias and Wariston display voracious sexual urges, the husbands of Lady Lambert and Lady Desbro' are depicted as willing cuckolds, Lord Desbro' showing more affinity for his horses than his wife or his committee responsibilities: "I'll do any thing, so I may rise time enough to see my Horses at night" (3.1.98-99). Robert Markley rightly observes that "the sexual inadequacies of the Puritans mark them as trespassers within the symbolic order of phallocentric law", and their "sexual incompetence and hypocrisy emphasize their political illegitimacy". ${ }^{34}$ In this order, the extra-marital desire of Behn's heroines becomes acceptable, and their efforts to repeal the 1650 "Act against Adultery and Fornication" in their council of ladies become an act against the tyranny of usurpers. The emphasis is different from that of Tatham's The Rump, where the council of ladies scene is placed much earlier, in 3.1 rather than 5.1, and where the salacious, vain, and cruel women attempt to pass laws to enable them to have more sex, following the example of contemporary interregnum satires. Pamphlets with the theme of women organising and presiding over their own government were popular during the 1650 s because they effectively and humorously expressed anxieties about the disruption of the established hierarchy. In a late example, Now or Never; or, A New Parliament of Women (1656), the women are made to exclaim: "we have bit so much of the bridle, that now we do intend to throw off the Rein of their Government, and Rule ourselves". 35 This kind of revolutionary freedom was satirised in these pamphlets, and in Tatham, but Behn's focus differs: the ladies' council attempts to pass laws wholly beneficial to the exiled cavaliers, legitimising and explaining the women's 
sexual desire (and their bawdy comments about cavaliers "stand[ing] to their principles"), associating the tyrannous adultery act with the Puritan parliamentarians. Loveless also appears at the council, disguised (apparently convincingly) as a woman called "Lady MakeShift", to present the petition for the repeal of the Act, and urging that "in a free state, why should not we be free" (5.1.266; a statement given to Lady Cromwell in The Rump). Aside, he gently mocks the women for their squabbles, and his motives are selfish, but he points out that the Act is "to the great detriment of most of the young Ladies, Gentlewomen, and Commonalty of England, and to the utter decay of many whole Families, especially when married to old men" (5.1.254-56). This phrase is added to Tatham and, although lighthearted, it aligns yoking old men and young women with tyranny and oppression. Through the metaphor of tyrannical marriages, Behn vindicates women's desire because it is set on cavalier freedom: as Markley continues, the "ideology of restoration" meant "the utopian union of desire and law". 36

Clearly, then, Behn was using her play to persuade those coming to the theatres that Whig rule offered "the true threat to 'liberties and properties', inverting the whig claim that only exclusion could safeguard these". ${ }^{37}$ But, as with many of Behn's plays, there are also criticisms made of cavalier/Tory culture in the liberty and property it offers women. The Roundheads certainly associates sexual liberty with the cavaliers, and the downfall of the parliamentary buffoonish upstarts is celebrated, but there are some uncomfortable moments where cavalier behaviour merges with Whig nastiness. For instance, in response to "Lady Make-Shift's" petition, Lady Desbro' proclaims that the council is for "the liberty and property of our sex" (5.1.267), recycling a well-known Whig phrase also spoken by the "Protestant Joiner" in the first scene of the play, and highlighting for the audience that cavalier principles offer more "liberty and property" than those of the Whigs. Kimberley Latta briefly mentions Lady Desbro's statement as an example of "ideological confusion", and, although it can be explained as showing the audience that the cavaliers offer freedom and honesty, it is worth asking whether Behn's play wholly supports this reading. ${ }^{38}$ For instance, the behaviour of Ananias and Freeman is shown to be very similar, particularly when Ananias helps Freeman to escape discovery by Lady Desbro's husband, and Loveless is later mistaken for a "He-Saint" (4.2.242) in Lady Lambert's rooms. Freeman also attempts to persuade Lady Desbro' to give in to his adulterous sexual advances in a comparable manner to Ananias's, only a scene after she is "ruffled" by the Whig preacher. Although the stage direction "ruffles" is absent from Freeman's scene, the printed text has breathless dashes in her speech indicating that some hurried action is taking place: "-unreasonable Freeman, not to have Patience until my Husband be hang'd a little" (4.1.28-29). Both heroines are also courted by the cavaliers for their money, something of which Ananias is frequently accused, and are "converted" to the cavaliers" cause. Further, Ananias is said to have been cuckolded by his wife and therefore to be enacting his own revenge on everyone, and this situation is disturbingly similar to Freeman's, who urges Loveless to "Revenge" himself on the parliamentarians who have confiscated his estates (1.1.175). For both parties, Presbyterian Whig and Tory cavalier, bedding women is to some degree about exerting and maintaining control, no matter how much Freeman dismisses cheating for power: "what's all this to Love?" (2.1.370). He exclaims rather too enthusiastically that upon Lord Desbro's death he will "greedily [...] seize the Forfeiture!" to which Lady Desbro' replies, "But what am I like to get if this Change do come?" (4.1.58). The ending of the play, while whole-heartedly supporting the cavaliers in their return to power, remains uncommitted as to whether Lady Desbro' will become "Lady Freeman" in name as well as nature and property. When Lady Desbro' puts herself into Freeman's protection at the end of the play, he rather ambiguously states, "I doubt you'll never be your own Woman again" (5.1.490-91): the most 
straightforward interpretation of this is that he apprehends that marriage to him will result in her loss of freedom; Freeman is surely shown to "tickle" his words to achieve his aims.

Behn's The Roundheads certainly attempts to display "Jack Presbyter in his proper habit", showing her audience that Whig nonconformists, rather than Jesuits, presented the most threat to the nation. In a world after Charles II, rule under the Protestant Duke of Monmouth and his Whig advisers looked bleak in comparison to the succession of the Catholic James. The play depicts the threat of Jack Presbyter in Behn's presentations of 1650s power-hungry parliament men, and lascivious, vengeful nonconformist preachers, enacting their purgation from government and subsequent punishment. Spreading sedition, attempting rape, confiscating property, and removing liberties were activities an audience could expect to see if they supported the Whig exclusionists. She subverts the Pope-burning tradition, utilised by the Whigs, and uses Whig slogans such as "liberty and property" and "free-born subjects" for satire, but also in more unexpected ways, including naming her cavalier hero "Freeman". Her faultless cavalier heroine, Lady Maria Desbro', appears "High for the Royal Cause in Cavelier" (Epilogue, 423 1. 2), likely named for the mother of Charles II and James II, the Catholic Queen Henrietta Maria, echoing yet subverting the reverence paid to the Protestant Elizabeth I by the Whig party. Although the play's overall message indicates the virility and desirable qualities of the cavaliers and the prosperity they would bring to England, and unreservedly celebrates the Restoration of the "great Heroick" (4.1.109) Charles II, Behn, characteristically, is also interested in asking whether women can ever obtain "liberty and property" in either parliamentary or cavalier worlds.

Dr Rachel Adcock, Loughborough University

\section{Notes}

$1 \quad$ Alan Marshall, in The Strange Death of Edmund Godfrey: Plots and Politics in Restoration London (Stroud: Sutton, 1999), concludes that Godfrey probably committed suicide.

2 See, for instance, Elizabeth Bennett Kubek, “Night Mares of the Commonwealth': Royalist Passion and Female Ambition in Aphra Behn's The Roundheads," Restoration 17 (1993): 88-103; and Robert Markley, “'Be Impudent, Be Saucy, Forward, Bold, Touzing, and Leud': The Politics of Masculine Sexuality and Feminine Desire in Behn's Tory Comedies," Cultural Readings of Restoration and Eighteenth-Century Theater, ed. Deborah Payne Fisk and J. Douglas Canfield (Athens: U of Georgia P, 2010) 114-40.

$3 \quad$ Aphra Behn, "The Roundheads," The Works of Aphra Behn: The Plays 1678-1682, ed. Janet Todd, 7 vols. (London: Pickering, 1996) 6: 365, Prologue, 11. 17-18.

4 Melinda Zook, "Religious Nonconformity and the Problem of Dissent in the Works of Aphra Behn and Mary Astell," Mary Astell: Reason, Gender, Faith, ed. William Kolbrener and Michal Michelson (Aldershot: Ashgate, 2007) 99-113 (106).

5 Zook, "Religious Nonconformity" 101.

6 A Poem on the Burning of the Pope (London, 1679).

$7 \quad$ The Solemn Mock Procession of the Pope, Cardinalls, Jesuits, Fryers \&c through the Citty of London, November $17^{\text {th }} 1680$ (London, 1680). 
John Miller notes that the revival of Pope burning, probably in 1673, was linked to the increased domination of politics by the "Catholic question": "before that the custom had been merely to light bonfires and fireworks on 5 November". See Miller, Popery and Politics in England: 1660-1688 (Cambridge: Cambridge UP, 1973) 183. The Solemn Mock Procession of the Pope, Cardinalls, Jesuits, Fryers, \&c: Through $y^{e}$ City of London, November $y^{e} 17^{\text {th }} 1679$ (London, 1679). Miller, Popery and Politics 185; Tim Harris, London Crowds in the Reign of Charles II: Propaganda and Politics from the Restoration until the Exclusion Crisis (Cambridge: Cambridge UP, 1987) 104. The Procession; or, The Burning of the Pope in Effigy (London, 1681) 2. Behn, "The Second Part of the Rover", in The Works of Aphra Behn: The Plays 16781682, ed. Janet Todd, 7 vols. (London: Pickering, 1996) 6: 365, Prologue, 11. 17-18.6: 231, 11. 26-32. Settle also wrote The Female Prelate (London: W. Cademan, 1680) which included what Behn called "fat Cardinals, Pope Joans, and Fryers" (1. 18), using the monstrosity of a pregnant female Pope to represent the popish penchant for intrigue and disorder. J. Douglas Canfield, “Tupping Your Rival's Women: Cit-Cuckolding as Class Warfare in Restoration Comedy," Broken Boundaries: Women \& Feminism in Restoration Drama, ed. Katherine M. Quinsey (Lexington: U of Kentucky P, 1996) 113-28 (121); Melinda Zook, "Contextualising Aphra Behn," Women Writers and the Early Modern British Political Tradition, ed. Hilda L. Smith (Cambridge: Cambridge UP, 1998) 7593 (81-82). Harris, London Crowds in the Reign of Charles II 130, 131. A Dialogue upon the Burning of the Pope and Presbyter in Effigie at Westminster, Novem. 51681 (London, 1681) 6. Tatham's final scene is set in front of "a piece of wood [...] set forth painted like a pile of Faggots and Fire" while the city apprentices shout "Roast the Rump" (Tatham, The Rump; or, A Mirror of the Late Times (London, 1660) 61). Behn has "a great Bonfire, with Spits, and Rump rosting, and the Mobile about the Fire" (5.1.492 SD): this indicates a more lavish prop, or even a real bonfire, to compete with the visual power of popular street bonfires. The theatre was able to accommodate more spectacular effects than a private house, where The Rump was performed. However, even though the rival King's Company performed Settle's contemporary Whig play The Female Prelate with a "Stake and Faggots" prepared by "Priests with Lighted Torches to kindle the Fire" to burn the Duke of Saxony, the female Pope's unwilling lover, the stage directions do not indicate that the torches ever touch the faggots to light the bonfire (Elkanah Settle, The Female Prelate (London, 1680) 70). Staging a real bonfire, given its propensity to provoke strong feelings (and possibly violence) in those watching, would have been dangerous, both to the theatre building and the actors who could have been at risk of being burnt like effigies of the Pope or Jack Presbyter. However, without the danger involved in producing a real bonfire, the final scene would surely pale in comparison with an open-air Pope-burning.. 
Wariston becomes a ballad singer/seller, Ananias enters "crying Almanacks" (5.1.507 SD), and Hewson enters disguised as a country dancer and performs. Ballads and almanacs were familiar platforms for Whig propaganda and were adopted by Tories after 1680.

19 Natasha Korda, “Judicious Oeillades': Supervising Marital Property in The Merry Wives of Windsor," Marxist Shakespeares, ed. Jean E. Howard and Scott Cutler Shershow (London: Routledge, 2002) 82-103 (100); Natalie Zemon Davis, "Women on Top," Society and Culture in Early Modern France: Eight Essays (Stanford, CA: Stanford UP, 2003) 124-51 (140).

20 Canfield, “Tupping Your Rival's Women” 117-18.

21 Raymond P. Stearns, The Strenuous Puritan: Hugh Peter, 1598-1660 (Urbana: U of Illinois P, 1954) 418, cited in Carla Gardina Pestana, "Peter, Hugh (bap. 1598, d. 1660)," Oxford Dictionary of National Biography (2004) $<\mathrm{http}: / /$ www.oxforddnb.com. $>$.

22 Harris London Crowds in the Reign of Charles II 170.

23 Kenneth Richards, "The Restoration Pageants of John Tatham," Western Popular Theatre: The Proceedings of a Symposium sponsored by the Manchester University Department of Drama, ed. David Mayer and Kenneth Richards (London: Methuen, 1977) 49-73 (51).

${ }^{24}$ Paula R. Backsheider suggests that processions often took place on the stage and 'were major ways that playwrights incorporated political commentary': they began by 'celebrating national values' before disclosing 'an angry point', and this appears to be part of what Behn is doing in The Roundheads ('From The Emperor of the Moon to the Sultan's Prison', Studies in Eighteenth-Century Culture, 43 (2014), 1-26 (1)).

Francis Montalvan, The Naked Truth; or, A Plain Discovery of the Intrigues of Amorous Fops (London: Thomas Palmer, 1673) 22-23. See, for instance, Behn, "On a CONVENTICLE," The Works of Aphra Behn: Poetry ed. Janet Todd, 7 vols. (London: Pickering, 1992) 1: 355, likely written at a similar time to Behn's play and D'Urfey's The Royalist (1682), with which it shares the phrase "Holy Bag-Pipe". Behn also quibbles on the word "turn", meaning to convert or persuade (both spiritually and sexually), in The Feigned Courtesans, when the lascivious preacher Tickletext desires to "turn" the women of Rome, to which Petro (the courtesans' pimp) replies: "Turn her, signor? Alas, any way, which way you please" ("The Feigned Courtesans," "The Rover" and other Plays, ed. Jane Spencer (Oxford: Oxford UP, 1998), 1.2.25-26).

Lady Desbro' was probably played by Betty Currer, famous for comic female roles. She played Lady Fancy in Sir Patient Fancy (1678) who also claims puritan preachers were tempted by her body: the brethren "do so sneer upon me, pat my Breasts, and cry fie, fie upon this fashion of tempting Nakedness" ("Sir Patient Fancy," The Works of Aphra Behn: The Plays 1678-1682, ed. Janet Todd, 7 vols. (London: Pickering, 1996) 6: 2.1.39-40). Montalvan, The Naked Truth 60-61. 
Behn argued later for the (useful) political potential of the stage in her dedication of The Lucky Chance (1687) to Laurence, Lord Hyde, the Earl of Rochester, where she writes that "plays and public diversions were thought, by the greatest and wisest of states [Greece and Rome], one of the most essential parts of good government" ("The Lucky Chance," "The Rover" and other Plays, ed. Jane Spencer (Oxford: Oxford UP, 1998) 231, Epistle Dedicatory, 11. 29-31.

Ben Jonson, "The Alchemist," "The Alchemist” and Other Plays, ed. Gordon Campbell (Oxford: Oxford UP, 1995) 2.5.47. Jonson's plays were popular on the Restoration stage and the rights to perform them were owned by the rival King's Company. Performances of The Alchemist were popular in the early Restoration period. The Tales and Jests of Mr Hugh Peters (London: S. D., 1660) 26. Behn, "The Feigned Courtesans" 3.1.553. Thomas Otway's preface to Behn's The City Heiress also refers to an unnamed preacher, likely meant to reference Titus Oates, a "home-spun Ananias", who "by old Arts' played 'new Tricks, | And fills the heads of Fools with Politicks" ("The City Heiress," The Works of Aphra Behn: The Plays 16821696, ed. Janet Todd, 7 vols. (London: Pickering, 1996) 7: 9, Prologue, 11. 31-34). Thomas Edwards, The First and Second Part of Gangraena (London: Printed by T. R. and E. M. for Ralph Smith, 1646) 31-32. Some sectarian congregations did sanction this sort of behaviour. Markley, "'Be Impudent, Be Saucy, Forward, Bold, Touzing, and Leud': The Politics of Masculine Sexuality and Feminine Desire in Behn's Tory Comedies" 125. Now or Never; or, A New Parliament of Women (London, 1656) 4. Markley, “'Be Impudent, Be Saucy, Forward, Bold, Touzing, and Leud': The Politics of Masculine Sexuality and Feminine Desire in Behn's Tory Comedies" 125. Harris, London Crowds in the Reign of Charles 138. Kimberley Latta, "Aphra Behn and the Roundheads," Journal for Early Modern Cultural Studies 4.1 (2004): 1-36 (27).

Rachel Adcock is Lecturer in English at Loughborough University's Department of English and Drama. She has published articles in several journals on seventeenth-century Baptist women's writing and is currently completing a monograph on this research. She is interested in all kinds of women's writing, and has recently co-edited (with Sara Read and Anna Ziomek) an anthology of works by early-modern women titled Flesh and Spirit: An Anthology of Seventeenth-Century Women's Writing, forthcoming with Manchester UP. Address: Department of English and Drama, Loughborough University, Leicestershire, LE11 3TU, UK. [email: R.C.Adcock@1boro.ac.uk]

Keywords: Aphra Behn; Whigs and Tories; Restoration comedy; nonconformity; pageantry 
List of Captions:

FIGURE 1. "The Solemn Mock Procession of the Pope, Cardinalls, Jesuits, Fryers, Nuns exactly taken as they marcht through the Citty of London, November the $17^{\text {th }}, 1680$ " CTrustees of the British Museum

SOURCE: The Solemn Mock Procession of the Pope (London: [Produced by Stephen College, "The Protestant Joiner"] for John Oliver, 1680).

FIGURE 2. William Hogarth, "Burning ye Rumps at Temple Barr" (1726) @Trustees of the British Museum

SOURCE: Samuel Butler, Hudibras (London, 1726), plate 11.

FIGURE 3. "Satire on Hugh Peters" (c.1662-63) CTrustees of the British Museum SOURCE: British Museum Satires 968, in Frederic Stephens and Mary Dorothy George, Catalogue of Political and Personal Satires in the Department of Prints and Drawings in the British Museum (London: British Museum Press, 1870) vol. 1. 